\title{
Three Centuries of
}

Conflict in East Timor 


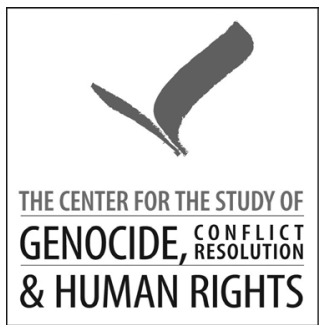

\section{Genocide, Political Violence, Human Rights Series}

Edited by Alexander Laban Hinton, Stephen Eric Bronner, and Nela Navarro

Alan W. Clarke, Rendition to Torture

Lawrence Davidson, Cultural Genocide

Daniel Feierstein, Genocide as Social Practice: Reorganizing

Society under the Nazis and Argentina's Military Juntas

Alexander Laban Hinton, ed., Transitional Justice: Global Mechanisms and Local Realities after Genocide and Mass Violence

Alexander Laban Hinton, Thomas La Pointe, and Douglas Irvin-Erickson, eds., Hidden Genocides: Power, Knowledge, Memory

Douglas Kammen, Three Centuries of Conflict in East Timor

Walter Richmond, The Circassian Genocide

Irina Silber, Everyday Revolutionaries: Gender, Violence, and Disillusionment in Postwar El Salvador

Samuel Totten and Rafiki Ubaldo, eds., We Cannot Forget: Interviews with Survivors of the 1994 Genocide in Rwanda Ronnie Yimsut, Facing the Khmer Rouge: A Cambodian Journey 


\section{Three Centuries of Conflict in East Timor}

DOUGLAS KAMMEN

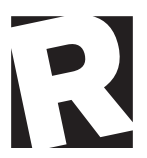

RUTGERS UNIVERSITY PRESS

NEW BRUNSWICK, NEW JERSEY, AND LONDON 


\section{LIBRARY OF CONGRESS CATALOGING-IN-PUBLICATION DATA}

Kammen, Douglas Anton, author.

Three centuries of conflict in East Timor / Douglas Kammen.

pages $\mathrm{cm}$-(Genocide, political violence, human rights series)

Includes bibliographical references and index.

ISBN 978-0-8I35-74IO-3 (hardcover : alk. paper)-ISBN 978-o-8I35-74II-O (e-book (epub))-ISBN 978-o-8I35-74I2-7 (e-book (web pdf))

I. Timor-Leste-History. 2. Political violence-Timor-Leste-History. I. Title. II. Title: 3 centuries of conflict in East Timor.

DS649.5.K36 2015

959.87-dc23

20I404I36I

A British Cataloging-in-Publication record for this book is available from the British Library.

Copyright (@) 2015 by Douglas Kammen

All rights reserved

No part of this book may be reproduced or utilized in any form or by any means, electronic or mechanical, or by any information storage and retrieval system, without written permission from the publisher. Please contact Rutgers University

Press, I06 Somerset Street, New Brunswick, NJ 089or. The only exception to this prohibition is "fair use" as defined by U.S. copyright law.

Visit our website: http://rutgerspress.rutgers.edu

Manufactured in the United States of America 